\title{
モンテカルロ評価における危険不確定パラメータの検出法*1 Detection of Influential Uncertain Parameters in Monte Carlo Evaluation
}

\author{
元 田 敏 和*2 \\ Toshikazu Motoda
}

Key Words : Simulation, Flight Testing, Monte Carlo Method, System Evaluation, Statistical Test

\begin{abstract}
In aerospace projects preflight evaluation is crucial for mission success, because flight testing in a real environment is often difficult or impossible. Monte Carlo simulation is a powerful tool for the preflight evaluation because a nonlinear system incorporating various uncertain parameters can be evaluated directly. Monte Carlo simulation has been used in various aerospace projects throughout the world as the computer power increases. After the system evaluation, it is important to detect influential uncertain parameters which cause significant performance degradation so that measures for the system improvement can be studied. However, detecting those parameters is often uneasy because various uncertain parameters are incorporated simultaneously and their magnitudes are randomly generated in Monte Carlo simulation. An interaction of more than two uncertain parameters might be affected. This paper presents a simple approach to detect influential uncertain parameters applying a statistical test to the Monte Carlo results.
\end{abstract}

記

号

$$
\begin{aligned}
& E: \text { 期待値 } \\
& M: \text { 不確定パラメータ数 } \\
& N: \text { 不確定パラメータ・ベクトル数 } \\
& n: \text { システム要求を満たさないケース数 } \\
& P: \text { ロールレート } \\
& P_{\min }: \text { 各不確定パラメータの累積確率値 } \\
& P_{\mathrm{s}}: \text { シッション達成確率 } \\
& P_{|z|}::|z| \text { の累積確率 } \\
& P_{\chi^{2}}: \chi^{2} \text { の累積確率 } \\
& R: \text { ヨーレート } \\
& R_{0}: \text { ヨーレートの初期値 } \\
& s^{2}: \text { 標本分散 } \\
& V: \text { 分散 } \\
& z: \text { 標本平均の標準化変数 } \\
& \alpha: \text { 色除率 } \\
& \delta_{\mathrm{a}}: \text { エルロン舵角 } \\
& \dot{\delta}_{\mathrm{e}}: \text { エレボン舵角レートリミット } \\
& \delta_{\mathrm{r}}: \text { ラダー舵角 } \\
& \dot{\delta}_{\mathrm{r}}: \text { ラダー舵角レートリミット } \\
& \varepsilon: \text { 不確定パラメータ・ベクトル } \\
& \varepsilon(j): \text { 不確定パラメータ・ベクトルの } j \text { 番目の要素 } \\
& \bar{\varepsilon}: \text { 不確定パラメータの標本平均 }
\end{aligned}
$$

*1 C 2007 日本航空宇宙学会

平成 18 年 5 月 10 日原稿受理

特許出願中, 特願 2006-30256

$* 2$ 宇宙航空研究開発機構

$$
\begin{aligned}
\Theta & : \text { ピッチ角 } \\
\mu & : \text { 母平均 } \\
\sigma & : \text { 母分散 } \\
\chi^{2} & : \text { 標本分散の } \chi^{2} \text { 値 } \\
\Psi & : \text { 方位角 }
\end{aligned}
$$

$$
\text { 1.はじめに }
$$

航空宇宙機の開発においては, 実環境での飛行試験によ り，あらかじめシステム全体の動作を確認することが困難 な場合も多い．よって，飛行前の事前評価か非常に重要と なる．モンテカルロ・シミュレーションは樣々な不確定要 因を考慮した事前評価が可能なツールであり，近年の計算 機能力の大幅な向上に伴い国内外のプロジェクトにおいて 広く利用されるようになってきた ${ }^{1 \sim 7)}$. 個別のシステムにも 依存するが, 通常不確定要因として存在するものには, 温 度や風等の環境条件, 慣性特性・空力モデル・アクチュエー タモデル等の機体モデル誤差, センサの計測誤差, 初期条 件などがある . これらの存在下におけるシステムの挙動を 事前に評価することが必要であり, モンテカルロ法は評価 手法として次のような優れた特徵を持つ.1) 非線形システ ムの直接評価が可能である.2) 仮定した不確定パラメータ の発生頻度に対応したミッション達成確率や被評価状態量 の分布が結果として得られる.3) 複数の不確定パラメータ の影響も結果に現れる．4）標本調査であるため，実行する シミュレーション回数 (計算負荷) は, 不確定パラメータ の数に依存しない .

ところがモンテカルロ評価の結果がミッション要求を満 足しない場合，逆にシステムの性能やロバス卜性に重大な 
文献 [8-9] の手法

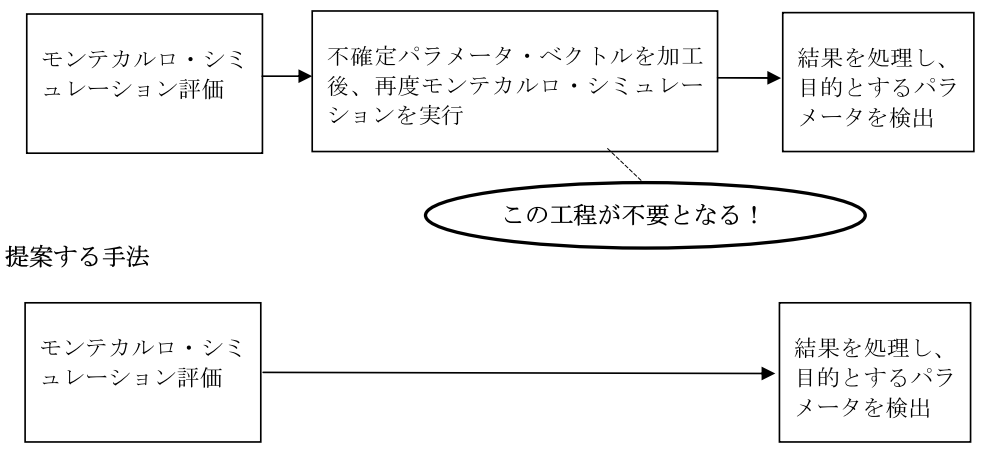

第 1 図 従来手法に対する利点

影響を及ぼす不確定パラメータを見つけ出すことは必ずし も容易ではない，モンテカル口法では，樣々な不確定パラ メータを同時に，しかも光れらの大きさをランダムに加え るため，2 つ以上の不確定パラメータがシステムに複合的 に作用することがあるためである . システム要求に対する 影響が大きな不確定パラメータを, 以下本稿では危険不確 定パラメータと呼ぶことにする．

危険不確定パラメータを見つけることは，システムの弱 点の原因を特定することであり，改善検討を行うためには 必ず必要となる.具体例を挙げれば，1) 危険不確定パラ メータとしてセンサ誤差やアクチュエータのレートリミッ トが検出された場合，対象となるハードウェアの改修が必 要かもしれない，2) 空力特性が危険不確定パラメータとし て検出されれば，設定した空力モデルの不確定性の範囲を より正確に知り，弚の範囲を限定するための地上試験が有 効かもしれない，3) 風条件か問題となるなら, 誘導制御ソ フトの改修が必要かもしれない. 以上, どのような対策が 効果的であるかは個別のシステムと光の時々の状況に依存 するが , 少なくとも原因が特定されない限り，上記のよう な対応策の検討は不可能である .

危険不確定パラメータの検出方法はこれまでに文献 8,9) により提案されている.しかしこれらの方法では，モンテ カルロ評価後に色険不確定パラメータを検出するために再 度モンテカルロ・シミュレーションが必要となるため, 時 間的コストが大きい . 評価対象となるシステムにもよるが， モンテカルロ評価は数日〜数週間を要することもありうる そこで本稿では再度のモンテカルロ・シミュレーションを 必要とせず, システム評価後直ちに危険不確定パラメータ を検出可能な簡易的な手法を提案する . 文献 8,9$)$ の手法 に対する本手法のメリットを第 1 图に示す .

以下では 2 節で提案する危険不確定パラメータ検出法の 原理について述べ，3 節で統計的検定を利用したパラメー 夕検出法の詳細を述べる. 4 節で適用例を示し, 最後に 5 節でまとめる .

\section{2. モンテカルロ法とパラメータ検出の原理}

はじめにモンテカルロ・シミュレーションによるシステ ム評価の概要を記す．次に，光の評価結果を用いた危険不

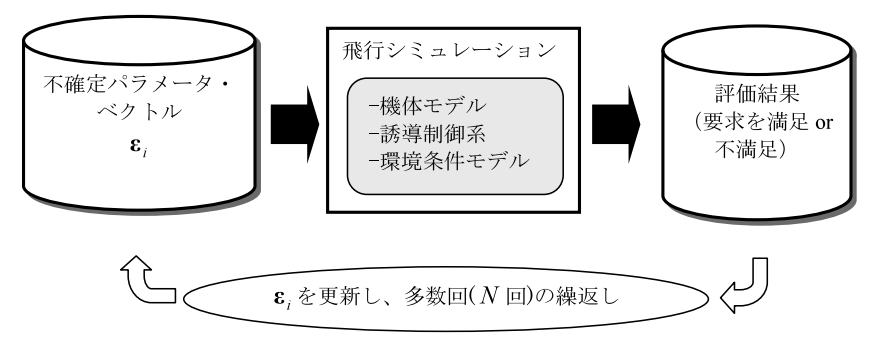

第 2 図 モンテカルロ・シミュレーションによるシステム評価

確定パラメータ検出法の原理について述べる .

2.1 モンテカルロ評価 現実には，先に述べたような 樣々な不確定要因が存在する .モンテカルロ・シミュレー ションにより，これらの想定されるすべての不確定パラメー タの影響を反映した非線形システムの総合評価が可能であ $3^{10,11)}$.

モンテカルロ・シミュレーションによるシステム評価の 概念を第 2 図に示す．まず個々の不確定パラメータの確率 分布を設定し，乥の大きさをランダムに発生させて不確定 パラメータ・ベクトル $\varepsilon_{i}$ を生成する . 考慮する不確定パラ メータ数が $M$ 個であるとき, $\varepsilon_{i}$ は $M$ 次元ベクトルとな る.次にシミュレーション・モデルに $\varepsilon_{i}$ を組み込み, 飛行 シミュレーションを一度実行する. 光して結果が要求を満 足しているかどうかを判定する.この一連のシミュレーショ ン評価を， $\varepsilon_{i}$ を更新しながら多数回繰り返せばミッション 達成確率や目的とする出力状態量の分布が推定できる . こ れがモンテカルロ法によるシステム評価である .

各不確定パラメータの設定は, 基本的にはハードウェア の性能や試験結果などの物理現象を基に，適切な範囲と分 布形を決定する．なかには物理現象に関わる情報が殁どな いパラメータも存在するが, 弚の場合でも設計の前提条件 として適切であろうと考えられる值を設定する．情報がな いから何も解析できないということではなく，ここで重要 なのは前提条件として設定した不確定性の大きさと評価結 果との関係が明確になるということである．

いま, $N$ 回のシミュレーションを実行するとすれば， $\varepsilon_{i}$ も $N$ 個発生させる必要がある. この樣子を第 3 図に示す. モンテカルロ評価の結果, $n$ 回だけ要求を満たさなかった 
$N$ 個の不確定パラメータ・ベクトル

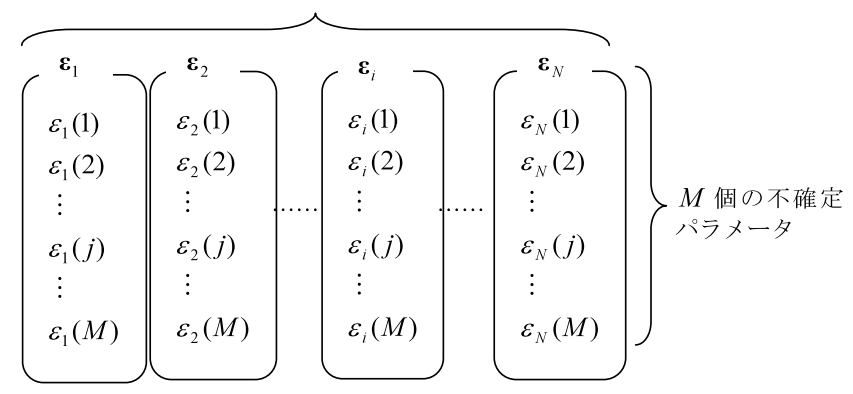

第 3 図 発生させる不確定パラメータ・ベクトル

とすればミッション達成確率は，

$$
P_{\mathrm{s}}=1-n / N
$$

以上のように , モンテカルロ・シミュレーションでは樣々 な不確定パラメータを同時に，かつ关れらの大きさをラン ダムに加えるため，あらゆる不確定パラメータを考慮した 非線形システムの総合的な評価が可能である. 多数回のシ ミュレーション評価の中でシステム要求を満足しないケー スか現れるが , このときシステムに重大な影響を及ぼす危 険不確定パラメータが必ず存在するはずである . しかし , こ れらを特定することは必ずしも容易ではない．この欠点を 補う 1 つの簡便な方法として，感度解析がある．感度解析 は個々の不確定パラメータを 1 個ずつ個別に加えて光れら の影響を調査するものであり，各不確定パラメータ単独の 影響を評価できる.しかし， 2 個以上の不確定パラメータ の複合的な影響によってシステム要求が満足できなくなる ケースも現実には存在し, これらの危険不確定パラメータ まで感度解析で検出することは不可能である. 乥こで，こ のような場合にも危険不確定パラメータの検出が可能な手 法について検討した . 本手法の原理を次に述べる .

2.2 パラメータ検出法の原理 モンテカルロ・シミュ レーションでは, 各不確定パラメータの大きさは設定した 分布に従ってランダムに発生させる . 不確定パラメータの 分布形は任意に設定すればよいが， $N$ を大きくすれば， $j$ 番目の值 $\left(\varepsilon_{i}(j), i=1, \cdots, N\right)$ は設定した元の分布に近 づく.

いま $N$ 回のモンテカルロ評価の結果 , $n$ 回だけシステム 要求を満足できなかったとする.このとき対応する $n$ 個の 不確定パラメータ $\varepsilon_{i}(j)$ の分布が, 仮定した元の分布 (例 えば正規分布) から無作為に抽出したとは考えられない程， 分布形が大きく異なっていれば，この $j$ 番目の不確定パラ メータはシステム要求を満たさない原因，つまり危険不確 定パラメータである可能性が高い．この性質を利用して，危 険不確定パラメータを検出する .ここで「元の分布と異な る」ことを数学的に表現するため, 平均及び分散について の相違を考える.$n$ 個の分布と元の分布でこれらの值を比 較し, 大きく異なるかどうかを判定する .

航空機や宇宙往還機などの場合には，発生させる不確定 パラメータの分布の平均を 0 とすれば，正の值と負の値が

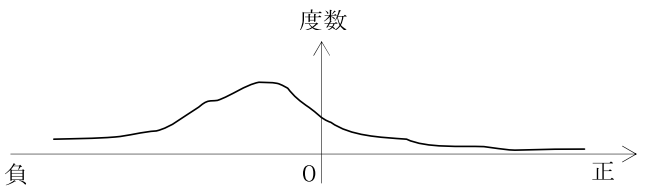

(a ) 平均值の偏り

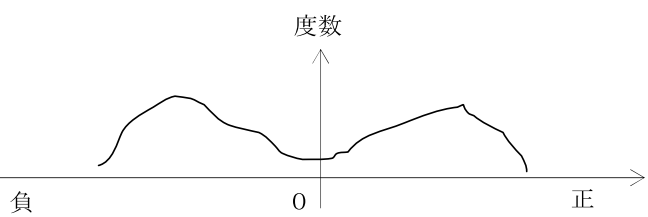

(b) 分散の偏り

第 4 図 $n$ 個の不確定パラメータの分布の偏り

同程度の影響を縦運動に及ぼすとは考えにくい.つまり，縦 運動に影響する危険不確定パラメータの分布は第 4 図 (a) のように正側または負側に偏る可能性が高い.この場合，n 個の標本の平均と元の分布の平均の偏差により危険不確定 パラメータを検出できる．

一方横運動に関しては，機体形状が左右対称であるとす れば危険不確定パラメータの正側と負側で機体に及ぼす運 動は逆方向にはなるが, 乥の影響の大きさは不確定パラメー タの符号に依存しない，つまり，横運動には色険不確定パ ラメータの絶対值の大きさか効く可能性が高い . 例えば元 の分布が正規分布のときには, 危険不確定パラメータの分 布は第 4 図 (b)のようになると推定される.よって , この場 合は元の分布との分散の違いで判定するのが合理的である .

以上より，危険不確定パラメータ検出の原理についてま とめる.まず, システム要求を満たさないケースに対応す る $n$ 個の不確定パラメータ・ベクトル $\varepsilon_{i}$ を取り出す . 次 に $M$ 個の各不確定パラメータ $\left(\varepsilon_{i}(j), j=1, \cdots, M\right)$ につ いて, 乥れ平均と分散を計算し，母集団の平均及び分 散と比較する. 乥して母集団との違いか顕著な不確定パラ メータを，危険不確定パラメータとして検出する．

\section{3. 統計的検定を利用したパラメータ検出法}

システム要求を満足しないケースに対応する不確定パラ メータ・ベクトル $\varepsilon_{i}$ に含まれる各要素について，光れぞれ 平均と分散を母集団と比較し, 弚の相違を調べる.この相 違の大小を判定するために，仮説検定を利用する．乥こで， 最初に平均及び分散の仮説検定について，弚れ光れ述べる。 次に，仮説検定を利用した危険不確定パラメータの検出手 順についてまとめる . 最後に , 本手法の適用と利用法につ いて考察する。

帰無仮説を「標本 (要求を満足しないケース) は母集団 から無作為に抽出された」とし，この帰無仮説の下で標本 の発生確率を求める. 求めた発生確率が著しく小さければ 帰無仮説を棄却し，「標本は何らかの意图で母集団から抽出 された」と考える.つまりここでは, 乥の不確定パラメータ はシステム要求に重大な影響を及ぼす危険不確定パラメー タであると判定する . 
3.1 平均值の検定 帰無仮説に基づき，標本平均が母 集団から無作為に抽出されるときに得られる平均值の発生 確率を算出する.設定した不確定パラメータ $\varepsilon$ の集団分 布の平均 $\mu$, 分散 $\sigma^{2}$ とする. 取り出した標本数を $n$, 標本 平均を $\bar{\varepsilon}$ とすれば，

$$
\bar{\varepsilon}=\frac{1}{n} \sum_{i=1}^{n} \varepsilon_{i}
$$

ここで, 標本平均 $\bar{\varepsilon}$ の期待値 $E$ と分散 $V$ は,

$$
\begin{aligned}
& E(\bar{\varepsilon})=\mu \\
& V(\bar{\varepsilon})=\sigma^{2} / n
\end{aligned}
$$

となる12). 第 2 式は, 取り出した標本数 $n$ が大きいほど標 本平均のばらつきは小さくなることを表す .つまり $n$ が大 きいほど , 標本平均 $\bar{\varepsilon}$ の分布は母平均 $\mu$ のまわりに集中す ることを表す．

母分散 $\sigma^{2}$ が末知である場合には, 標本数 $n$ が小さいと き標本分散 $s^{2}$ と $\sigma^{2}$ の乘離が大きいため, $t$ 検定を行う必 要がある ${ }^{12)}$. しかし , モンテカルロ評価では , あらかじめ 分布を設定して人工的に不確定パラメータを発生させるた め, $\sigma^{2}$ は既知である .よって，標本数にかかわらず正規分 布を仮定した検定を用いる．標本平均を標準化すると，

$$
z=\frac{\bar{\varepsilon}-\mu}{\sqrt{\sigma^{2} / n}}
$$

標準化変数 $z$ は, 近似的に標準正規分布 $N(0,1)$ に従う ${ }^{12)}$. ここで， $|z|$ の值に対応する標準正規分布の上側累積確率 $P_{|z|}$ を求める . これは統計表や市販の統計ソフトを用いて 容易に得られる . 標本が母集団から無作為に取り出される とき, 現実に得られた標本平均の発生確率が $P_{|z|}$ である . 危険率を $\alpha$ とすれば，

$$
P_{|z|} \leq \alpha / 2
$$

のとき帰無仮説を棄却する . (5) 式で表される萧却域を第 5 図に示す. 確率密度関数の裾の斜線部分の面積が上側と下

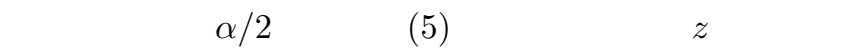
の領域に入る . 得られた標本が無作為に取り出されたと仮

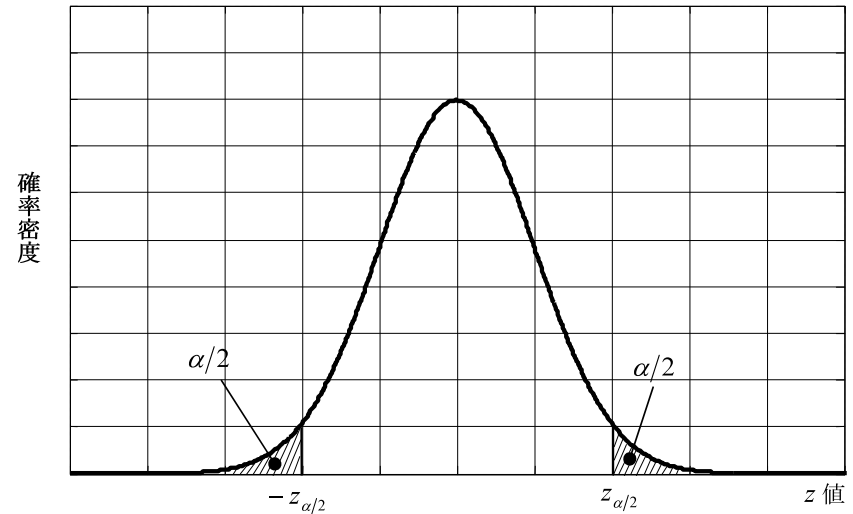

第 5 図 正規分布と累積確率
定すると, 弚の標本平均は $\alpha$ にも満たない小さな確率でし か起こりえないことを意味する．このような小さな確率で しか起こりえないことか現実に起こっているため，標本が 無作為に取り出されたとは考えにくく，このとき帰無仮説 を棄却する．光して，対応する不確定パラメータは危険不 確定パラメータであると判定する．

3.2 分散の検定 標本分散が母分散と乘離しているか どうかについては, $\chi^{2}$ 分布を用いて検定を行う . 標本分散 を $s^{2}$ とすると，次式で与えられる．

$$
s^{2}=\frac{1}{n-1} \sum_{i=1}^{n}\left\{\varepsilon_{i}-\bar{\varepsilon}\right\}^{2}
$$

このとき $\chi^{2}$ 值は次式から得られる .

$$
\chi^{2}=(n-1) s^{2} / \sigma^{2}
$$

これは自由度 $(n-1)$ の $\chi^{2}$ 分布に従う. (7) 式の $\chi^{2}$ 値に 対応する下側累積確率を $P_{\chi^{2}}$ とすると, 帰無仮説が充却さ れる条件は，

$$
P_{\chi^{2}} \leq \alpha / 2
$$

または，

$$
P_{\chi^{2}} \geq 1-\alpha / 2
$$

である . (8a) 式は標本分散が母分散と比べて小さすぎる場 合，(8b) 式は大きすぎる場合についての㶳却条件であり， この㶳却域を第 6 図に示す.(8) 式の条件を満たすとき, 対 応する不確定パラメータは危険不確定パラメータであると 判断する。

3.3 検出手順 これまでに述べた平均及び分散の仮設検 定を用いた危険不確定パラメータの検出手順を述べる . 統 計的検定では, 分布の累積確率が危険率 $\alpha$ を超えるかどう かで判定する．累積確率の值が小さいほど，帰無仮説との 乘離が大きいことを表す．したがって，この累積確率の値 を各不確定パラメータについて求め, 兴の確率を小さい順 に並べればシステム要求への影響が大きい可能性が高い順 番となる . 以下にパラメータ検出手順を示す .

[1] $N$ 回のモンテカルロ・シミュレーションを実行し，

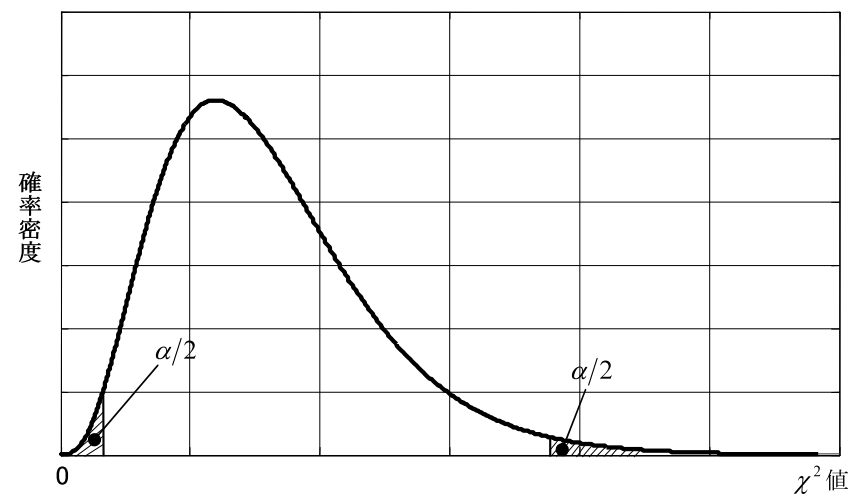

第 6 図 $\chi^{2}$ 分布と累積確率 
システム要求を満たさないケースに対応する入力不確定パ ラメータ・ベクトル $(n$ 個) を取り出す．

[2] $M$ 個の各不確定パラメータについて，(4) 式より $z$ を，(7) 式より $\chi^{2}$ を計算する.この手順を第 7 図に示す.

[3] 得られた $z, \chi^{2}$ を累積確率に変換する. $z$ について は, $|z|$ に対応する分布の裾の面積で表される上側累積確率 $P_{|z|}$ を算出する $\cdot \chi^{2}$ についは下側累積確率 $P_{\chi^{2}}$ が 0.5 を 超えるときは上側累積確率の值に変更する．つまり，

$$
P_{\chi^{2}}>0.5 \text { のとき, } P_{\chi^{2}}=1-P_{\chi^{2}}
$$

このように処理すれば累積確率 $P_{|z|}$ 及び $P_{\chi^{2}}$ が , 小さい順 に棄却域に近くなる。

[4] $M$ 個の各不確定パラメータについて $, P_{|z|}, P_{\chi^{2}}$ の いずれか小さい方の值を, 兴の不確定パラメータの累積確 率值 $P_{\min }(j)$ とする.つまり，

$$
P_{\min }(j)=\min \left\{P_{|z|}(j), \quad P_{\chi^{2}}(j)\right\}
$$

乥して, 各不確定パラメータに対応する $M$ 個の $P_{\min }(j)$ を小さい順に並べ, 棄却域 $\alpha / 2$ よりも小さいものをシステ 厶要求への影響が大きいものと判定する.上記, [3] 及び [4] の処理手順を第 8 図に示す.

3.4 本手法の適用について 本手法の適用にあたっては 留意すべき点がある. 弚の 1 つは不確定パラメータが時系 列で変化する場合であり, 例えばセンサ出カのランダムノ イズなどのケースである .この場合は時系列で变化する入 力信号の平均と分散等の統計量が指定される. しかし, こ れらの統計量は毎回のシミュレーションごとに変化するわ けではなく一定值であるため，本手法は適用できない． また他のケースとしては, システム要求を満たさないケー

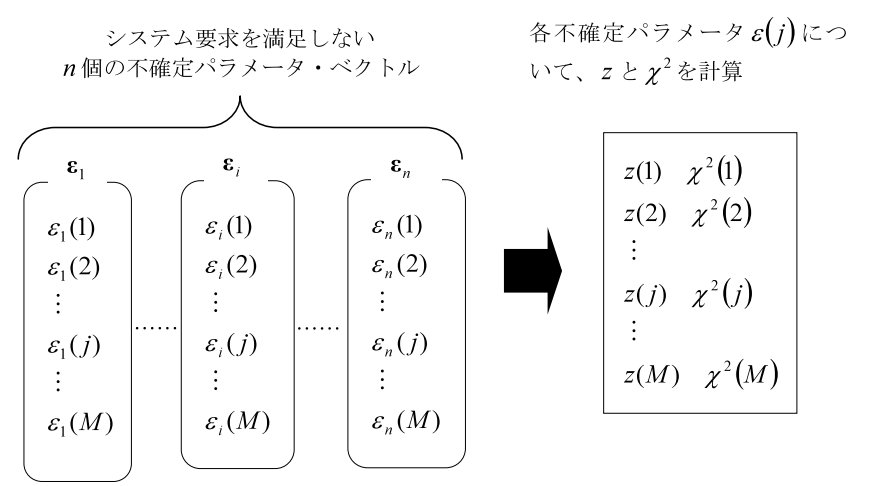

第 7 図 統計量 $\left(z, \chi^{2}\right)$ の算出

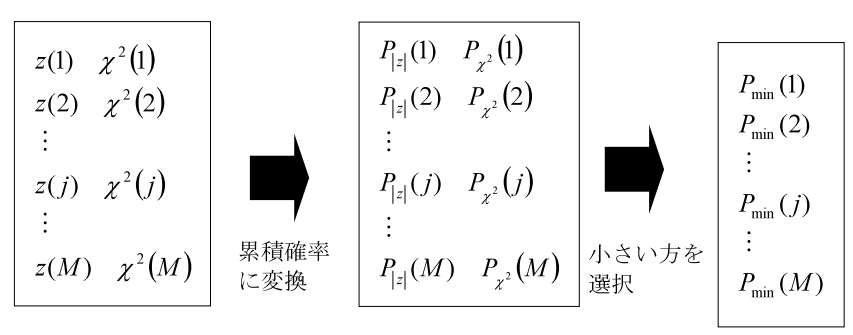

第 8 図 統計量の処理手順
ス数が極端に少ない場合，つまり $n$ が小さすぎてデータが 不十分な場合には検定精度が悪化する .この場合は，危険 不確定パラメータを検出できない可能性が高くなる．

以上のような場合は文献 8,9) に示す手法により，パラ メータ検出を実行すればよい，ただし，モンテカルロ・シ ミュレーションの実行が再度必要であることは先に述べた とおりである . 本手法の利点はモンテカル口評価終了後, 直 ちに光の結果を用いて危険不確定パラメータの検出が可能 なことである．したがって本手法が利用可能ならば，まず 本手法を適用することによって，検出作業を進めるのか効 率的である。

\section{4. パラメータ検出例}

オーストラリア・ウーメラ飛行場において 1996 年に実 施された小型自動着陸実験 (ALFLEX) を例として取り上 げ, 光のモンテカルロ評価結果に本検出法を適用し, 光の 有効性を示す . はじめに ALFLEX の概要とモンテカルロ 評価結果例を示し, 次に本パラメータ検出法を適用した結 果を示す．さらに検出された危険不確定パラメータが，実 際にシステムに重大な影響を及ぼしているパラメータであ ることを検証する 。

4.1 ALFLEX の概要と評価結果 ALFLEX は,将来 の宇宙往還機実現に向けて自動着陸技術を確立するために 実施された ${ }^{13 \sim 15)}$. 南オーストラリア州・ウーメラ飛行場に おいて実施され，全 13 回の着陸実験に成功した . まず, 実 験機はへリコプタに吊されて飛行し，滑走路手前 $2700 \mathrm{~m}$ ， 高度 $1500 \mathrm{~m}$ において分離される. 兴の後, 実験機は各セ ンサ情報を搭載計算機に取り込み，組み込まれた誘導制御 ロジックに従って，自動飛行により滑走路に着陸する．本 実験の概要を第 9 図に示す。

本実験の実施にあたっては，事前に飛行システムの挙動 を確認するためにモンテカルロ・シミュレーションによる システムの評価を行った．モンテカルロ評価において考慮 した不確定パラメータの種類を第 10 図に示す.ここで考 慮した不確定パラメータの数は約 100 個である.第 11 図 に 5000 回のモンテカルロ評価結果例を示す .いくつかの ケースで接地状態の要求值を満たしていないことがわかる. 第 11 图に示す状態量の他にも接地要求はあり，1 項目でも 接地要求を満たさないケースは全体の約 $1.3 \%$ であった . ま

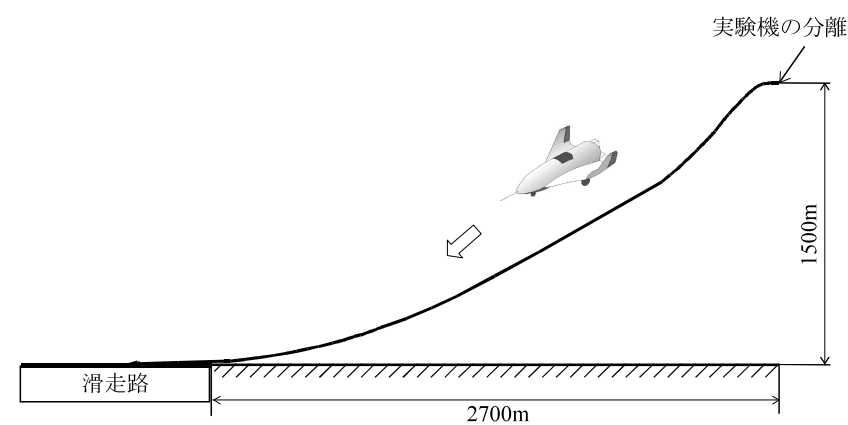

第 9 図 小型自動着陸実験（ALFLEX） 
第 1 表 パラメータ検出結果

\begin{tabular}{ccllc}
\hline No. & \multicolumn{1}{c}{$P_{\min }$} & \multicolumn{1}{c}{ 不確定パラメータ } & $P_{|z|}$ & $P_{\chi^{2}}$ \\
\hline$[1]$ & $6.25 \times 10^{-11}$ & エレボンレートリミッタ $\dot{\delta}_{\mathrm{e}}$ & $6.25 \times 10^{-11}$ & $7.64 \times 10^{-4}$ \\
{$[2]$} & $6.93 \times 10^{-10}$ & ラダーレートリミッタ $\dot{\delta}_{\mathrm{r}}$ & $6.93 \times 10^{-10}$ & $1.67 \times 10^{-3}$ \\
{$[3]$} & $5.16 \times 10^{-5}$ & 分離時ヨーレート $R_{0}$ & $5.94 \times 10^{-2}$ & $5.16 \times 10^{-5}$ \\
\hline
\end{tabular}

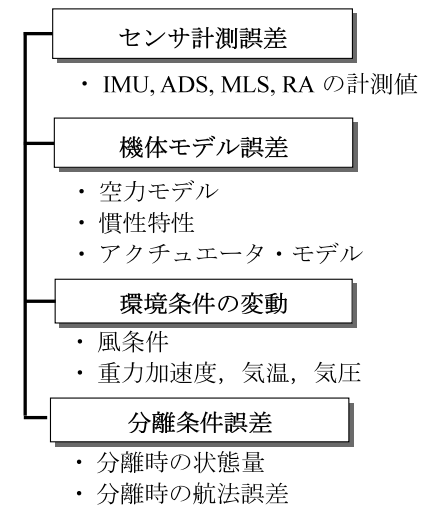

第 10 図 不確定パラメータの種類

接地時状態量のばらつき
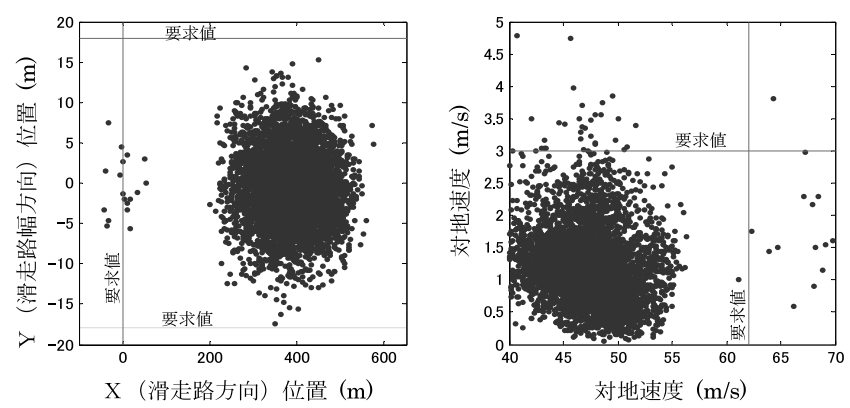

第11 図 モンテカルロ評価結果例（5000 回試行）

た，この他に飛行中に運動が不安定となって接地に至らず， 着陸できないケースが 17 回 $(0.34 \%)$ 発生した .

接地時状態量に影響する不確定パラメータについては, 個々の不確定パラメータの影響を調べる感度解析により， ノミナルケースとの差が明らかになる . 例えば接地時沈下 率であれば, ノミナルケースでの沈下率，不確定パラメー 夕を含む場合の沈下率は光れ光れ数值的に表され，ノミナ ルケースとの差は数值的に表現できる .このためノミナル 状態との差の大きさにより，危険不確定パラメータはある 程度は特定可能である. これに対して飛行中に不安定とな る場合は, 例えば “不安定度” のようなものを数值的に表す ことはできないため, 得られる結果は安定か不安定 (途中 で飛行不能) の 2 通りの情報しか得られない．つまり，ノ ミナルケースとの数值的な差の情報は得られない .

実際に不確定パラメータを個別に加える感度解析では不 安定となるケースは 1 ケースも現れなかった .このため， モンテカルロ評価結果で不安定となる 17 回のケースでは 2 個以上の不確定パラメータの複合的な効果により，不安定 現象が発生しているものと考えられる .

以上より，本パラメータ検出法の有効性を示すため，感

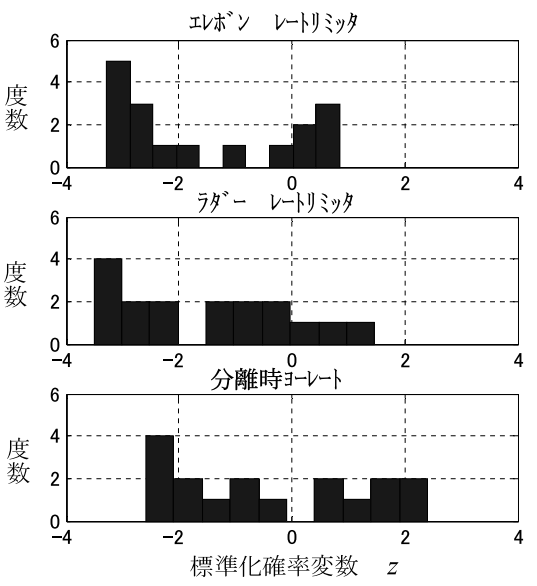

第 12 図検出された不確定パラメータの度数分布

度解析では解析不可能である機体運動が不安定となるケー スを取り上げて本手法を適用し，危険不確定パラメータの 検出を試みた .

4.2 パラメータの検出結果 機体運動が不安定となっ た 17 回のケースについて, 弚れに対応する入力不確定パラ メータ・ベクトル $\varepsilon_{i}(i=1, \cdots, 17)$ を取り出し, 不安定現 象に影響する危険不確定パラメータを検出する . 3.3 項の 手順に従って， $\varepsilon_{i}$ の要素である各不確定パラメータ $\varepsilon(j)$ に ついて，(4)，(7) 式を用いて关れ䖟れ $z(j) ， \chi^{2}(j)$ を求め る. 次に, これらに対応する下側累積確率 $P_{|z|}, P_{\chi^{2}}$ を求 めて，(10) 式より $P_{\min }(j)$ を求める.この $P_{\min }(j)$ が $\alpha / 2$ よりも小さいときに, 不確定パラメータ $j$ は不安定ケース に大きく影響していると判断する .

次に危隃率 $\alpha$ の設定方法についての 1 つの考え方を記す． この例では不確定パラメータの数は約 100 であるため, 各 パラメータに対応する $P_{\min }$ も 100 個程度算出されること になる .これは, 各パラメータについて 1 回ずつ, 合計 100 回の検定を実行していることに相当する．つまり，全く危 険不確定パラメータが存在しないとしても，偶然に 1 個程 度は，いずれかの $P_{\min }$ 值が $1 / 100$ 程度の小さな值をとる ことが容易に起こりうる．したがって棄却域を定めるため の危険率 $\alpha$ の值として，この例では $1 / 100$ よりもさらに 1 桁小さい $\alpha=1 / 1000$ と設定して仮説検定を行った .

このようにして危険不確定パラメータを検出したところ， 第 1 表のようにエレボンのレートリミッタ $\dot{\delta}_{\mathrm{e}}$, ラダーのレー トリミッタ $\dot{\delta}_{\mathrm{r}}$, 実験機分離時のヨーレート $R_{0}$ が検出され た . $P_{\min }$ の值も $\alpha / 2$ よりもかなり小さく, 帰無仮説の下 では殁ど起こりえないような小さな確率となっていること がわかる.また， $\dot{\delta}_{\mathrm{e}}$ 及び $\dot{\delta}_{\mathrm{r}}$ につては平均値のずれを表 す $P_{|z|}$, 一方 $R_{0}$ については分散のばらつきを表す $P_{\chi^{2}}$ が， 乥れ艺れ $P_{\min }$ の值となっていることがわかる . 検出され 
第 2 表 モンテカルロ評価結果 (5000 回試行)

\begin{tabular}{ccc}
\hline ケース番号 & 除いた不確定パラメータ & 不安定回数 \\
\hline $1-1$ & なし & 17 \\
$1-2$ & $\dot{\delta}_{\mathrm{e}}, \dot{\delta}_{\mathrm{r}}, R_{0}$ & 0 \\
\hline $2-1$ & $\dot{\delta}_{\mathrm{e}}$ & 7 \\
$2-2$ & $\dot{\delta}_{\mathrm{r}}$ & 10 \\
$2-3$ & $R_{0}$ & 3 \\
\hline
\end{tabular}

た不確定パラメータを標準化した $z$ にいて，17 ケースの 度数分布を第 12 図に示すが，確かに $\dot{\delta}_{\mathrm{e}}$ 及び $\dot{\delta}_{\mathrm{r}}$ の值は負側 に偏っている.これはアクチュエータのレートリミッタ值 がノミナル状態よりも小さくなって舵角レートの制限か強 くなっていることを表す．一方， $R_{0}$ については，正側・負 側共にばらつきが大きく, 分散が大きくなっていることが わかる.このことから, 分離時のヨーレートが正・負を問 わず大きくなるときにシステムに重大な影響を及ぼしてい ると推測できる .

4.3 検出結果の検証 次に検出された 3 つの不確定パ ラメータが, 実際に不安定現象の原因となっていることを 確認する . 検出された 3 つの不確定パラメータの全部また は一部を除き, 他の条件は全く変えずに再度モンテカルロ 評価を行い確認した . 5000 回の評価の結果，不安定現象が 発生した回数を第 2 表に示す.

すべての不確定パラメータを組み込んだケースが第 2 表 の (1-1) のケースであり, 不安定現象は 17 回発生してい る.これに対し，前節で検出された 3 つの不確定パラメー 夕 $\dot{\delta}_{\mathrm{e}}, \dot{\delta}_{\mathrm{r}}, R_{0}$ を除いたものが (1-2) のケースであるが， この場合不安定現象は一度も発生していない．したがって， 検出された 3 つのパラメータが不安定現象に関与してい ることが確認できる．次に，検出された 3 つの各パラメー タが光れ不安定現象に寄与していることを確認する ため，各パラメータを1つずつ除いて結果を調べたのが， (2-1)〜(2-3) のケースである.すべてのケースにおいて 失敗数は 17 よりも減少しており，検出された 3 つの各不 確定パラメータは, 弚れ不安定現象に影響しているこ とが確認できる .

検出された不確定パラメータの内容から, 舵角のレート が小さ制限され, かつ, 分離時のヨー運動が励起されて いるときに，機体運動を安定化するための制御コマンドに 舵面アクチュエータが追従できなくなり，不安定現象が発 生しているものと考えられる .これらの組み合わせの影響 を確認するために , ノミナル状態にこれら 2 つの不確定パ ラメータのみを同時に加えたシミュレーションを実施し確 認した . 加えた不確定パラメータの大きさは第 12 図の分

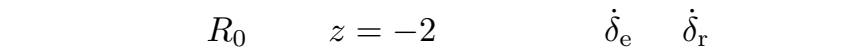
は $z=-3$ とした.第 13 図にシミュレーションで得られた 時間履歴を示す.上から横運動の状態量 $\Phi, \Psi, P, R$ を 示し，下 2 段にエルロン舵角 $\delta_{\mathrm{a}}$ 及びラダー舵角 $\delta_{\mathrm{r}}$ と光れ らのコマンドを破線で示す. (a) 図に $\left(\dot{\delta}_{\mathrm{e}} R_{0}\right)$ の組合せを 加えた結果を示すが, エレボン・アクチュエータのレート リミッタが小さく制限されているため, エルロン舵角がコ マンドに追従できず，ロール運動が発散していることがわ

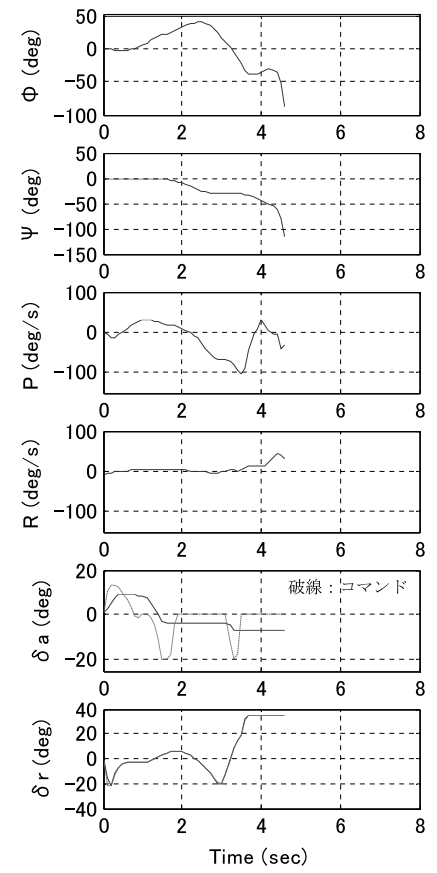

(a) $\left(\dot{\delta}_{\mathrm{e}} R_{0}\right)$ の組合せ

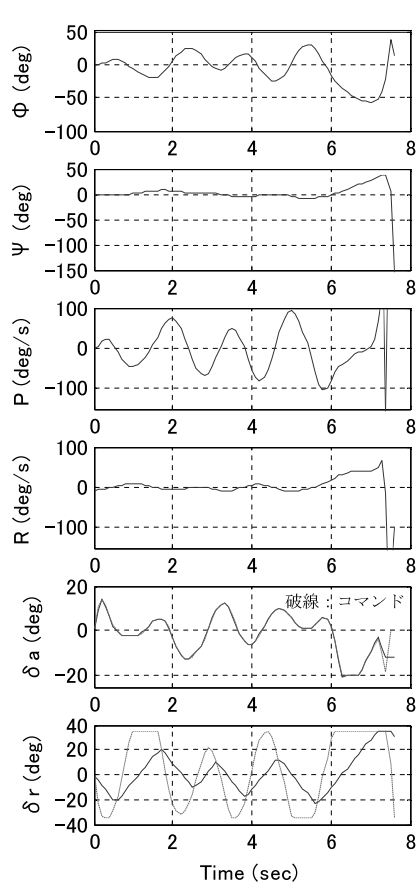

(b) $\left(\dot{\delta}_{\mathrm{r}} R_{0}\right)$ の組合せ
第13図検出された不確定パラメータの影響

かる．また右側の $(\mathrm{b})$ 図は $\left(\dot{\delta}_{\mathrm{r}} R_{0}\right)$ を加えた結果であるが， この場合はラダー舵角がコマンドに追従できず横運動が発 散していることがわかる .

以上より，前節て検出された 3 つの不確定パラメータは, 不安定現象に対する危険不確定パラメータであることか確 認できた .

\section{5. ま と め}

モンテカルロ評価結果に重大な影響を及ぼす危険不確定 パラメータの検出方法を提案した . 本手法の適用にあたつ ては, ある程度の失敗ケースの標本数が必要である等の留 意すべき点はあるが, 文献 8,9)の手法と異なり再度のモ ンテカルロ評価を必要としないため, 時間的コストが大幅 に軽減され効率的に検出作業を進めることができる.特に 設計の初期段階においては失敗ケース数も少なくないため, 本手法の利便性は高い . 危険不確定パラメータの検出法を 用いてシステム改善のための情報が効率的に得られること により, 評価ツールとしてのモンテカルロ法の利便性はさ らに向上することが期待される．

\section{参 考 文 献}

1) Shakarian, A.: Application of Monte-Carlo Techniques to the 757/767 Autoland Dispersion Analysis by Simulation, AIAA Paper 83-2193, 1983.

2) Ray, L. R. and Stengel, R. F.: Application of Stochastic Robustness to Aircraft Control Systems, J. Guid. Control Dynam., 14 (1991), pp. 1251-1259.

3) Desai, P. N., Schofield, J. T. and Lisano, M. E.: Flight Reconstruction of the Mars Pathfinder Disk-Gap-Band Parachute Drag Coefficients, J. Spacecraft Rockets, 42 (2005), pp. 672 676.

4) Mase, R. A., Antreasian, P. G., Bell, J. L., Martin-Mur, T. J. 
and Smith Jr., J. C.: Mars Odyssey Navigation Experience, J. Spacecraft Rockets, 42 (2005), pp. 386-393.

5) Motoda, T., Miyazawa, Y., Ishikawa, K. and Izumi, T.: Automatic Landing Flight Experiment Flight Simulation Analysis and Flight Testing, J. Spacecraft Rockets, 36 (1999), pp. 554-560.

6) 二宮哲次郎, 鈴木広一, 塚本太郎 : 高速飛行実証機フェーズ II の 誘導制御系評価，JAXA RR-04-002，2004.

7) Hamada, Y., Ninomiya, T., Katayama, Y., Shinomiya, Y., Matsumoto, K., Yamamoto, M., Sawai, S., Ueno, S. and Hayashi, K.: Feasibility Study for Precise Lunar Landing Using SELENE-B Lander Configuration, JAXA-RR-05-013E, 2005.

8) Motoda, T. and Miyazawa, Y.: Identification of Influential Uncertainties in Monte Carlo Analysis, J. Spacecraft Rockets, 39 (2002), pp. 615-623.

9) Motoda, T.: Simplified Approach to Identifying Influential Uncertainties in Monte Carlo Analysis, J. Spacecraft Rockets, 41 (2004), pp. 1071-1075.
10) Stengel, R. F.: Flight Dynamics, Princeton University Press, Princeton, 2004, pp. 375-385.

11) Mooney, C. Z.: Monte Carlo Simulation, 1st ed., Sage Publications Inc., Thousand Oaks, CA, 1997, pp. 1-65.

12) 東京大学教養学部統計学教室編: 統計学入門, 東京大学出版会, 東京，1997, pp. 94-99, 148-149, 191-204.

13) Miyazawa, Y., Ishikawa, K., Motoda, T., Izumi, T., Sagisaka, M., Hata, T. and Onuma, H.: Flight Control System for the Automatic Landing Flight Experiment, AIAA Paper 963782, 1996.

14) Miyazawa, Y., Nagayasu, M. and Nakayasu, H.: Flight Testing of ALFLEX Guidance, Navigation and Control System, ICAS-98-1.1.3, Proceedings of the 21st Congress of the International Council of the Aeronautical Sciences, Melbourne, Australia, 1998.

15) Miyazawa, Y., Motoda, T., Izumi, T. and Hata, T.: Longitudinal Landing Control Law for an Autonomous Reentry Vehicle, J. Guid. Control Dynam., 22 (1999), pp. 791-800. 